\title{
Zataraseni sebou
}

\section{Zuzana Svobodová}

\section{Envigogika 13 (2) - Recenzované články/ Reviewed articles}

Publikováno / Published 29. 12. 2018

DOI: $\underline{10.14712 / 18023061.579}$

\begin{abstract}
Abstrakt
Když lidé rezignují na osobní, bytostnou vztahovost a vazebnost $\mathrm{k}$ pravdě, $\mathrm{k}$ tomu co je, pak je taková sebestřednost cestou ke ztrátě orientace a vnímání smyslu existence, které se projevují např́ílad násilím či zoufalstvím. Skrze přicházející výzvu, slovo, logos, je možné najít cestu ze zatarasenosti sebou. Odpovídání na výzvu k odpovědnosti značí odvrácení (metanoein) $z$ orientace $k$ oddělenosti, sebestřednosti, $k$ vztahovosti, $k$ vědomí relačnosti k druhým, světu i Pravdě. $K$ odpovědi na toto $k$ pravdě vyzývající slovo máme jako lidé prostor svobody. Jako lidské bytosti máme možnost žít v prostředí dia-logu, dia-logu jako živlu, ze kterého může vzejít společenství, které nežije jen samo sobě.
\end{abstract}

\section{Klíčová slova}

dialog; logos; metanoein; vztahovost; existence; výchova; prostředí

\begin{abstract}
When people give up their personal, existential relatedness or their bonds towards the truth, towards what is, then self-centeredness is seen as a pathway to losing one's perception of the meaning of existence. This inclination can become manifested by violence and despair. Through the incoming and challenging word - logos - one can find a way out of being locked in oneself. Responding to the call for accountability involves turning away (metanoein) from being oriented to separation, secession, and self-centeredness to relationality, the consciousness of one's ties with others, the world and the Truth. For being able to answer this word, which calls us to participate in truth, we as humans have the space of freedom. As human beings we can come to a dia-logue as a living environment, dia-logue as an element, from which community may arise - a community that does not live solely for itself.
\end{abstract}

\section{Keywords}

dialog; logos; metanoein; relationship; existence; education; environment 


\section{Úvodem}

Tento text by mohl být vnímán jako odpověd' Janě Dlouhé na její minulý editorial tohoto časopisu ${ }^{1}$, nebo jako pokus o navázání dialogu, který byl otevřen. Co můžeme dělat za daného stavu věcí, kdy vztah k tomu, co je, co je živé, co se uskutečňuje, "nemáme“, nebo lépe: kdy skrze tento vztah nežijeme? Proč vlastně skrze něj nežijeme? Protože jej již nepěstujeme, nestaráme se o něj. Proč vlastně? Protože na to nemáme čas. Proč vlastně? Protože svůj čas věnujeme pro nás ted' a zde důležitějším věcem. Řetěz příčin, o němž psala Jana Dlouhá, je skutečně složitý, ale jako lidským bytostem nám nezbývá skutečně nic jiného, ptáme-li se po pravdě toho, co jest, abychom sestupovali k pramenům. Pro Aristotela to bylo něco, co nazýval př́ćčinou - pro nás je dnes př́čina většinou kauzalitou, což je jen zlomek toho, čím byla Aristotelovi - a poznání příčiny nás dle Aristotela přibližuje k pravdě. ${ }^{2}$ Ve dvacátém století mnozí myslitelé volali po návratu ke kořenům, $\mathrm{k}$ pramenům, počátkům. ${ }^{3}$ V následujícím textu nabízím jednu z odpovědí vyplývající, pramenící nejen z teorie, náhledu, ale neméně i z mého povolání a $z$ toho, co ve své praxi ${ }^{4}$ dělám: učím.

\section{Priamos a Achilleus}

Dovolím si začít u Homéra. Konkrétně v závěru Iliady, ve dvacátém čtvrtém zpěvu: „Lítému Achilleovi spíš, bohové, pomáhat chcete,

[40] který rozvahu nemá ni slušnost a v hrudi mu chybí

citlivé, povolné srdce - jak lev má ukrutnou mysl,

který své odvážné mysli a veliké síle se poddá,

vrhá se na stáda lidí a takto si získává žrádlo.

Takto i Achilleus pozbyl dar lítosti, nežije stud v něm,

[45] který velice může i škodit i prospívat lidem." 5

Těmito slovy se s výčitkami obrací Foibos neboli Apollón na bohy s cílem obměkčit je a vymoci zastavení hyzdění mrtvoly Hektora, jehož Achilleus, šílející smutkem nad smrtí Patrokla, vláčel přivázaného za vůz tažený koňmi. Achilleus je líčen jako lev, který má odvážnou a ukrutnou mysl, dle Homéra mu však chybí rozvážnost, slušnost, lítost a stud, citlivé a povolné srdce.

\footnotetext{
${ }^{1}$ Dlouhá, J. (2018). Editorial 2018/XIII/1. Envigogika, 13(1).

https://doi.org/10.14712/18023061.576.

${ }^{2}$ Srov. Aristotelés. (2003) Metafyzika. Praha: Rezek, s. 70nn. Aristotelés. (1996) Fyzika. Praha: Rezek, s. 50nn.

${ }^{3}$ Srov. např. Weilová, S. (1996). Dobro, mez a rovnováha: Výbor ze Sešitů. Praha: Mladá fronta, s. 46, 50-51, 69, 71, 125, 127. Weil, S. (1949). L'enracinement: Prélude à une déclaration des devoirs envers l'être humain. Paris: Les Éditions Gallimard. Dostupné na: http://classiques.uqac.ca/classiques/weil_simone/enracinement/weil_Enracinement.pdf, s. 180, 186. Heidegger, M. (2006). Básnicky bydlí člověk. Praha: OIKOYMENH, s. 11-17, 29-37, 139. Heidegger, M. (2004). Věda, technika a zamyšlení. Praha: OIKOYMENH, s. 9-13, 40-44. Heidegger, M. (2008). Rozvrh fenomenologické interpretace Aristotela. Praha: OIKOYMENH, s. 54-59. Lévinas, E. (1997). Totalita a nekonečno: Esej o exterioritě. Praha: OIKOYMENH, s. 92-97.

${ }^{4} \mathrm{O}$ vztahu teorie a praxe nejnověji např. Steel, S. (2018). Teacher Education and the Pursuit of Wisdom: A Practical Guide for Education Philosophy Courses. New York: Peter Lang, s. 8-9.

${ }^{5}$ Homér. (1980). Ílias. Přel. Rudolf Mertlík. Praha: Odeon, s. 451.
} 
Podle následujícího líčení v Íliadě však je srdce Achillea obměkčeno starcem Priamem. ${ }^{6}$ Tehdy zní Achilleovi v bolesti Priama bolest jeho vlastního otce, kterou bude cítit, až zemře Achilleus. $V$ tu chvíli tvář Priama mluví $k$ Achilleovi a on její řeči rozumí jako výzvě, slovy Emmanuela Lévinase, jako výzvě k odpovědnosti za druhého, k přijetí rukojemství, stavu, v němž se ocitáme dříve, než jsme si jej zvolili. ${ }^{7}$ Achilleus je schopen v Priamovi, dosud nepř́teli, vidět bratra, člověka, s nímž má společného víc, než si byl ochoten připustit.

Byl-li dosud Achilleus líčen v Íliadě jako lev, tak nyní se ze Iva stává člověk se srdcem. Nietzsche popsal trojí proměnu ducha na začátku spisu Tak pravil Zarathustra. ${ }^{8}$ První proměnou je, když se poslušný, ale Ize říci též: submisivní styl žití, čili duše připodobněná tažnému a nosnému zviŕeti, velbloudu, promění od stálého přitakávání k neustálému odpírání a touze rozhodovat vše sám, k autoritativnímu způsobu žití, pro který Nietzsche volí metaforu Iva. Co ale lev ani velbloud nedokážou, je stvořit něco nového. $K$ tomu je zapotřebí proměny třetí, ze Iva se má stát dítě. Mezi obrazy, kterými je popisován způsob života dítěte, zaujme zřejmě nejvíce zapomenutí. Vedle nevinnosti, početí, hry, kola ze sebe se roztáčejícího, prvního pohybu, posvátného Ano, je stav duše jako dítěte popsán: dítě je zapomenutím - je to obraz toho, že dítě nenese napríílad vztek, zlost a přičítání viny dlouho, je schopné zapomenout na ublížení ze strany druhých. Achilleus tedy není již Ivem, ale ve chvíli, kdy pozná v Priamovi také bratra v lidskosti, přestože zůstává členem nepřátelského tábora, přesto $v$ něm nyní vidí člověka, jako je on, začne s ním jednat jinak, s lítostí, slušností - $a$ je ochoten mu vydat mrtvé tělo jeho syna, Hektora.

Jak tato proměna nastala? Homér nám přináší ve svém eposu poselství, že tato proměna nastala skrze řeč a dar. Vztah $\mathrm{k}$ druhému jako bratru byl navázán skrze řeč, otevřenost, se kterou se Priamos odhaluje Achilleovi, řeč byla schopná oslovit, otevř́t dosavadní zatarasenost ${ }^{9}$ Achilleovu, který je ochoten prijmout Priama, jeho prosbu, jeho dar a pohostit jej. Nepř́tel se mu stává na jeden večer hostem.

Skrze vykročení starého Priama k mladému Achilleovi, byl Achilleus schopen překročit ze svého uzavření, smutku, šílení v zajetí vlastní bolesti, směrem $\mathrm{k}$ druhému, a tím také k vlastnímu nalezení lidskosti. Achilleus, dřive neschopný lítosti, nyní je tohoto schopen:

„Achilleus pro svého otce zas naříkal, chvílemi opět

Patrokla želel - zněl stanem jich obou žalostný nářek.

$\ldots$

nebot' s šedivou hlavou is šedivou bradou měl soucit," 10

(Otázku, zda byl Achilleus schopen kromě lítosti také studu, je třeba nechat otevřenou. Homér podává v závěru Íliady svědectví pouze o soucitu, lítosti a pohostinnosti Achillea,

\footnotetext{
${ }^{6}$ Srov. Homér. (1980). Ílias. Přel. Rudolf Mertlík. Praha: Odeon, s. 464-465 (Priamos před Achilleem, proměna: „měl soucit" - s. 465, ř. 8 ).

${ }^{7}$ Srov. Lévinas, E. (1997). Totalita a nekonečno: Esej o exterioritě. Praha: OIKOYMENH, (např.) s. 32-33.

8 Srov. Nietzsche, F. (1995). Tak pravil Zarathustra. Praha: Votobia, s. 21-23. ISBN 80-85885-79-4.

${ }^{9}$ Srov. Lévinas, E. (1997). Čas a jiné/Le temps et l'autre, Praha: Dauphin, s. 18n: „encombrement du Moi par le Soi-même". Srov. též Svobodová, Z. (2013). Čas: Lidská otázka po původu a smyslu.

Paideia: Philosophical e-journal of Charles University, roč. 10, č. 1, s. 11.

${ }^{10}$ Homér. (1980). Ílias. Přel. Rudolf Mertlík. Praha: Odeon, s. 465.
} 
dále pak o tom, že přislíbil, že vymůže u svých soukmenovců jedenáct dnů klidu v boji ${ }^{11}$, aby mohl být Hektor $v$ Tróji důstojně pohřben.)

Toto dílo, z prahu řecké literární kultury, končí líčením důstojného pohřbu Hektora, ochránce Tróji. Končí tedy usmírením, navázáním, vztahovostí. Už Hérodotos v 5 . století př. Kr. vnímal Homérovu Íliadu jako líčení sporu nejen mezi dvěma národy, mezi Řeky (nazývanými Achájci, Panachaioi) a Trójany (s jejich maloasijskými spojenci), ale jako spor mezi Evropou a Asií, a to jako spor mezi rovnocennými protivníky, celý spor má světodějnou perspektivu, připomíná nám Thomas $A$. Szlezák. ${ }^{12} \mathrm{O}$ to více považuji i dnes za podstatné zamýšlet se nad poselstvím íliady a nad tím, jak díky tomuto spisu a jeho významné recepci $\checkmark$ dějinách vzdělávání a kultury Evropy bylo utvářeno vědomí lidských hodnot a mravnosti vždyt́ na základě memorování a recitace tohoto díla byly vyučovány, vychovávány, kultivovány mnohé generace Evropanů. Přestože Platón odmítá Homéra jako toho, skrze kterého má probíhat výchova, víme, že sám jej cituje $s$ tím, že v mnohém s Homérem souhlasí. ${ }^{13}$ Pokud se zaměříme na tuto závěrečnou scénu z Íliady, co je jejím poselstvím? Považuji tento velký př́běh, tuto naraci, také (to jest mimo jiné) za svědectví o možné proměně $v$ duši člověka, o níž píše jako o existenciální "krizi" sebe například Paul Ricoeur ve své knize 0 sobě samém jako o jiném a připomíná na tomto místě ${ }^{14}$ vzájemně odlišné myslitele, Jeana Naberta, Gabriela Marcela a Emmanuela Lévinase, kteří rovněž vydávali svědectví o etické převaze "druhého jakožto sebe nad sebou" a společně s Paulem Ricoeurem považuji za podstatné, aby se „vlom druhého, který proráží uzavřenost téhož, setkal se souručenstvím toho rušivého pohybu, jímž se já dává $k$ dispozici jinému jako sobě. Nebot' by se nemělo stát, aby „,krize“ ipseity vedla k tomu, že sebeúctu nahradí nenávist vưči sobě." 15 Považuji tato slova Paula Ricoeura za klíčová pro jeho život a dílo zvláště od události, kterou „objevil tiché bratrství, které se rodí v rovnosti utrpení", za klíčová slova, kterým dala zrod bolest toho, kdo o bolesti nenávisti vůči sobě věděl mnoho, až př́liš mnoho - totiž jako otec syna, kterého nazýval "dítě návratu ze zajetí, dítě míru" 16 , který však svou svobodu neunesl.

\section{Adam a Eva}

Ve druhé části svého textu bych ráda ukázala s odkazem na biblickou tradici a konkrétně na její výklad v díle De civitate Dei (česky O Boží obci) Aurelia Augustina, jak skrze zaměření na sebe, které eliminuje relačnost, vztahovost, či lépe vazebnost k druhým a světu, skrze pýchu a neposlušnost, poznává člověk stud, jinakost a oddělenost - a zároveň, jak skrze výzvu, slovo, poslušnost, může člověk nalézt cestu k sobě, druhým i světu a skrze logos může navazovat vztahy a usilovat o soulad.

Ve třetí kapitole knihy Genesis ve Starém zákoně Ize číst příběh o tom, jak v zahradě $v$ Edenu had rozmlouval se ženou, Evou, a ta následně jedla plod stromu poznání dobrého a zlého, a nabídla též muži, Adamovi, který také jedl a poté, co se jim "otevřely oči", poznali

\footnotetext{
${ }^{11}$ Homér. (1980). Ílias. Přel. Rudolf Mertlík. Praha: Odeon, s. 469.

12 Srov. Szlezák, T. A. (2014). Za co vděčí Evropa Řekům: O základech naší kultury v řecké antice.

Praha: Oikúmené, s. 26.

13 Srov. např. Platón. (2001). Ústava. Praha: OIKOYMENH, s. 215 (II, 516d).

${ }^{14}$ Srov. Ricoeur, P. (2016). O sobě samém jako o jiném. Praha: OIKOYMENH, s. 185.

${ }^{15}$ Ricoeur, P. (2016). O sobě samém jako o jiném. Praha: OIKOYMENH, s. 186.

${ }^{16}$ Ricoeur, P. (2000). Myslet a věrit. (Rozhovor). Praha: Kalich, s. 122.
} 
svou nahotu, přikryli ji fíkovými listy a následně po rozmluvě s Bohem dostali od Boha kožené suknice, byli i s hadem potrestáni a také vyhnáni ze zahrady $\vee$ Edenu, aby nemohli vztáhnout ruku po stromu života. V posledním verši této kapitoly čteme prímo: „Tak [Bůh] člověka zapudil." (Gn 3,24)

V díle O Boží obci, knize XIV, od části 11 Augustin podává výklad tohoto činu Evy a Adama. Člověk byl stvořen jako spravedlivý a s dobrou vưlí. Tento čin byl odpadnutím od přikázání Boha, totiž daném v Genesi 2,17: „Ze stromu poznání dobrého a zlého však nejez. $\checkmark$ den, kdy bys z něho pojedl, propadneš smrti." Augustin vykládá, že první zlá vůle, která „předcházela všechny zlé skutky, byla spiše jakýmsi odpadnutím od díla Božího k dílům vlastním, nežli nějakým dílem, a ke špatným dílům proto, že byly podle sebe, ne podle Boha ... Dále: zlá vůle, ačkoli není podle prírody, nýbrž proti prírodě, protože je vadou, přece náleží té přirozenosti, jejíž je vadou, která nemůže existovat jinak než na přirozenosti - ale na té, kterou Stvořitel stvořil z ničeho, ne kterou sám ze sebe zplodil (jako zplodil Slovo, skrze které bylo stvořeno všecko)“ ${ }^{17}$. Augustin je přesvědčen, že nejen tělo člověka bylo stvořeno také z ničeho (prostřednictvím zemského prachu, který byl z ničeho), ale také lidská duše je dle Augustina stvořena z ničeho. Přirozenosti, které byly stvořené, jsou, nakolik jsou přirozenostmi, dobré. Porušení přirozenosti skrze zlo Ize napravit jen tím, že se přirozenost napraví, uzdraví - nikoli tím, že by se nějaká přirozenost odstranila. Jak málo bylo toto Augustinovo upozornění bráno $v$ potaz, není třeba připomínat, ani církev, tehdy ještě nerozdělená, zde neměla dostatek trpělivosti k vyhlížení pravdy a snaze o nápravu. Podle Augustina si člověk zde nemůže pomoci sám, ale přichází mu na pomoc spasitel, osvoboditel, Syn, který může člověka znovu osvobodit k tomu, aby jeho volní rozhodování nesloužilo již špatnosti (srov. J 8,36).

Možná je vhodné upozornit na ještě jednu poznámku Augustina, týkající se hodnocení Adamova přestupku. S odkazem na slova apoštola Pavla z Prvního listu Timoteovi: „Adam nebyl sveden, žena však byla svedena." ( 1 Tim 2,14) vykládá Augustin Adamovo přestoupení zákazu jíst ze stromu poznání dobrého a zlého nikoli tak, že uvěřil ženě, „jakoby mluvila pravdu, ale uposlechl ze společenské nutnosti" ${ }^{18}$. Adam zde podle Augustina upřednostnil prostředí prvního lidského vztahu, před prostředím, v němž mělo platit pravidlo, podle kterého měli $\vee$ Edenu žít, pravidlo daném Tím, kdo je do tohoto prostředí zavedl a kdo toto prostředí stvořil. Podle Augustina jen žena přijala hadovo sdělení jako pravdu, ale Adam "nechtěl být odtržen od své jediné společnosti ani ve společenství hříchu", nicméně inned Augustin dodává: „nebyl však proto méně vinen, jestliže zhřešil vědomě a úmysIně" ${ }^{19}$. Tedy Adam sice "nebyl sveden", ale "zhřešil". Svedeni jsou ti, kteří to, co činí, nepovažují za hřích, Adam však věděl. Augustin hovoří o Adamovi: "ušlo mu, jak bude muset být souzen jeho výrok: ,Žena, kterou jsi mi dal, ta mi dala a jedl jsem’ (Gn 3,12)“20 - tedy Adam opustil svůj počátek, v pýše se staví proti Bohu, dle Augustina proto, že se člověk líbí př́liš sám sobě, že se stává sám sobě počátkem, namísto žití z relačnosti, ze vztahu, žije ze sebe sama.

Augustin dále popisuje vstup studu a nestoudnosti do lidského života jako důsledek odpadnutí od společenství s Bohem. ${ }^{21}$ Odtržení se od kořenů, přináší podle tohoto biblického př́běhu - ve své symbolické řeči snad ještě trochu srozumitelného i nám - rozdělení, které

\footnotetext{
${ }^{17}$ Augustinus, A. (2007). O Boží obci: Knih XXII. Přeložila Julie NOVÁKOVÁ. Praha: Karolinum, s. 39.

${ }^{18}$ Augustinus, A. (2007). O Boží obci: Knih XXII. Přeložila Julie NOVÁKOVÁ. Praha: Karolinum, s. 40.

${ }^{19}$ Augustinus, A. (2007). O Boží obci, s. 40.

${ }^{20}$ Augustinus, A. (2007). O Boží obci, s. 40.

${ }^{21}$ Srov. Augustinus, A. (2007). O Boží obci, s. 46-50.
} 
na počátku nebylo. Nyní již žijeme v tomto rozdělení, ale stále nějak víme či tušíme, že celek, integrita, harmonie jako soulad rozmanitého (to je skutečně původní řecký význam termínu "harmonia", nikoli až plod multikulturní a pluralitní společnosti), je to, oč máme usilovat.

Sebeláska pak, podle Augustina, zakládá obec pozemskou, láska k Bohu obec nebeskou. ${ }^{22}$ Jak tato sebeláska nakonec vedla ke zmatení jazyků, jehož důsledkem je stav, který Augustin v XIX. knize a 7. kapitole líčí následovně: „Je to především rozmanitost jazyků, která lidi druh druhu odcizuje. Vždyt́ setkají-li se navzájem dva lidé a neminou-li se, nýbrž jsou-li nějak nuceni pobýti spolu, tu nezná-li ani jeden řeč druhého, spíše se sprátelí němé tváře, třeba různého druhu, než oni, ač jsou oba lidmi. Nemohou-li si totiž pro pouhou nestejnost řeči vespolek sdělit svoje myšlenky, nic nepomůže ke sdružení lidí ta veliká podobnost přirozenosti; ba člověk dlí raději se svým psem nežli s cizím člověkem. "23 Více než sedm století před Augustinem vyjádřil Aristotelés myšlenku, že lidská bytost, jediná obdařená řečí (logon de monon anthrópos echei tón zóón), vyhledává společenství na základě toho, že se může s druhými lidmi řeči dorozumět a také řeči s druhými sdílet príjemné a dobré: „řeč však jest určena $k$ tomu, aby naznačovala, co jest prospěšné a škodlivé, a tudíž také, co jest spravedlivé a nespravedlivé; tj. zajisté vlastní člověku před ostatními živočichy, že jediný má smysl pro dobro a zlo, pro právo a bezpráví a pro podobné věci; společenství těchto věcí pak vytvořuje domácnost i obec" (Aristotelés, Politika 1253a). A naopak, připomíná Augustin: Právě proto, že je člověk obdařen řečí, tak nerozumí-li jeden druhému, nechtějí spolu být, nejsou schopni si být přáteli, jsou na tom v takovém př́padě hůře, než "němé tváře".

Ve spisu De doctrina christiana (česky Křestáanská vzdělanost) Augustin říká jasně: „Žádná řeč přece nemá jiný důvod, než aby tomu, co říkáme, rozuměli lidé, kvůli jejichž porozumění mluvíme." 24 A zvláště nám, kdo učíme, je zapotřebí, abychom naslouchali navazujícím Augustinovým slovům: „A tak se má ten, kdo vyučuje, vyhnout všem slovům, která nevyučují." 25 To, oč jde, připomíná Augustin, není čistota stylu, ale pravé pochopení, milování pravdy. Láska $\mathrm{k}$ pravdě je však nejen cílem, je též v nás již také počátkem, kořenem: ,...znakem dobré povahy je milovat ve slovech pravdu a nikoli slova sama“26, láska k pravdě je tím, co nás vede, a pro Augustina podobně jako pro apoštola Pavla, který citoval Athéňanům verše Epimenidovy a Aratovy: je to Bůh, v něm žijeme, pohybujeme se a jsme, vždyt' jsme jeho děti $(S k 17,28)$, Slovo, které je alfou i ómegou, počátkem i koncem.

\section{Závěr}

$\checkmark$ homérské i $v$ biblické tradici se ukazuje sebestřednost či rezignace na osobní, bytostnou relacionalitu, vztaženost, vazebnost $k$ druhým (kteří jsou jiní), i ke světu jako cesta ke ztrátě schopnosti orientace a vnímání smyslu existence, které se projevují napríklad násilím či zoufalstvím.

\footnotetext{
22 Srov. Augustinus, A. (2007). O Boží obci, s. 58.

${ }^{23}$ Augustinus, A. (2007). O Boží obci, s. 258.

${ }^{24}$ Augustinus, A. (2004). Křestáanská vzdělanost: De doctrina christiana. Přeložila Jana NECHUTOVÁ. Praha: Vyšehrad, s. 188.

${ }^{25}$ Augustinus, A. (2004). Křestáanská vzdělanost: De doctrina christiana, s. 188.

${ }^{26}$ Augustinus, A. (2004). Křestáanská vzdělanost: De doctrina christiana, s. 189.
} 
Relacionalita nemůže být jen teoretickým tématem, tento pojem se vynořil z praktických, konkrétních ${ }^{27}$ závažných otázek a úkolů, které se týkají nejen každé lidské bytosti, ale všeho, co je životním „prostředím", v čem a díky čemu je život, který (dosud) je. Chceme-li v tomto prostředí žít, je třeba nám věrnosti pravdě, obracení se (metanoein) $k$ pravdě. Nestačí jen promýšlet různé metody a přístupy $v$ subjekt-objektovém přístupu $k$ světu, jak nás učil René Descartes, ale je nám zapotřebí ještě jiného přístupu $k$ tomu, co je, co existuje, žije, co se projevuje - naslouchání, nahlížení, staří Řekové to nazývali theoria, latiníci contemplatio. Jako lidské bytosti nemáme přijímat nic bez rozvažování, bez rozvážnosti - Achilleovi zprvu rozvažování chybělo (i nám je zapotřebí se rozvážnosti učit nasloucháním, nahlížením, teorií, kontemplací) - nechyběla mu přitom moc ani síla (právě ta i dnes provází mnohé, kteří se nezdržují rozvažováním a kteří tak nemají rozvážnost). Skrze slovo druhého, byl pohnut ve svém srdci a byl schopen rozvážnosti. Skrze druhého byl otevřen $\mathrm{k}$ sobě samému jako jinému, skrze živé, proměňující slovo, zaznívající či chvějící se v promluvě druhého byl schopen naslouchání a proměny. Pro naslouchání a objevování pravdy je zapotřebí pokora - což není submisivita (nestačí podle Nietzscheova podobenství velbloudí podoba ducha). Pro přijímání pravdy a $\mathrm{k}$ jejímu následování je třeba odvahy, často i odvahy velmi radikální, kdy nás následování pravdy odděluje od svých nejbližších, i od sebe samých, zacyklených, zatarasených $v$ sobě samých, proto zde bylo zmíněno vyprávění o Adamovi, který podle Augustina takového oddělení nebyl schopen.

Metanoia, odvaha pro pravdu překračovat dosavadní strukturu myšlení, není jednorázová aktivita. Je to samo výchovné prostředí, za které jsme jako učitelé a vychovatelé zodpovědní. Chceme-li vychovávat a působit v oblasti etického nebo environmentálního vzdělávání, pak to především pro nás znamená osvojovat si umění odpovídat na - člověka vždy předcházející - volání k odpovědnosti, obracet se (metanoein) z orientace k oddělenosti (nerelačnosti), ze sebestřednosti (biblicky "svévolnosti”, dle Komenského "samosvojnosti“) k vztahovosti, vazebnosti, $k$ vědomí relačnosti k druhým, světu i Pravdě. Otevřeným pro toto vnímání se člověk stává skrze přicházející logos, kterému je schopen nějak rozumět. $\mathrm{K}$ odpovědi na toto $\mathrm{k}$ pravdě vyzývající slovo máme jako lidé prostor svobody (Lévinas i Sartre upozorňují, že svoboda má nás - spíše, než že my bychom měli svobodu jako nějaké "něco", podobně jako Emanuel Rádl upozorňoval, že pravda má nás ${ }^{28}$ ). Nejen biblická tradice svědčí o tom, že člověk je díky této svobodě schopen vztahy $k$ sobě, druhým i světu likvidovat, pokouší-li se žít ve vztahu "mít“ k t/Tomu, co (Kdo) má nás, ale také o tom, že skrze slovo, logos, může znovu tyto vztahy navazovat, přijme-li, že již je, žije v tomto v pravém slova smyslu živlu, který jediný je živým veskrze. Slovo, „logos“ je podle biblické tradice počátek, princip, smysl, nejhlubší základ tvořivého aktu a zároveň jako takový je prostředník, mediátor, který je schopen prolomit každou totalitu, každé zatarasení.

Samotná existence, to jest vystupování z osobního bytování, se bez vědomí smysluplné vztahovosti k druhým a světu stává nemožnou. Dia-log je živoucí (to jest proměňující) prostředí, jímž je popisována i činnost Boha ${ }^{29}$, dia-log je živel, ze kterého může povstat společenství, které nežije jen samo sobě, ale které žije $z$ relace $k$ pravdě, dialog je život $\checkmark$ pravdě, která má nás. Žít $v$ otevřenosti takovému naslouchání slova, $v$ prostředí, kdy přijímáme z náhledu (theoria, contemplatia), v prostředí živého uskutečňujícího se dialogu, se

\footnotetext{
27 Čeština před dvěma generacemi užívala ještě slovo "srostitý" pro překlad „konkrétního" z latinského "con-cresco“.

${ }^{28}$ Srov. Lévinas, E. (1997). Totalita a nekonečno, s. 31. Sartre, J. P. (2006). Bytí a nicota. Praha: OIKOYMENH, s. 558. Rádl, E. (1946). Útěcha z filosofie. Praha: Čin, s. 13.

${ }^{29}$ Srov. dialog Lásky, Moudrosti a Moci u Komenského in: Komenský, J. A. (2017). Spisy o první filosofii. Praha: OIKOYMENH. Knihovna novověké tradice a současnosti, s. 654-715.
} 
však př́liš neučíme, naopak: převažující řeč v moderním vzdělávání nás podle George Granta ${ }^{30}$ od tohoto naslouchání odtrhává.

Obyčejný, dřevěný klíč zmiňuje Augustin jako nástroj, který je schopen odemknout to, co bylo zavřeno, a já dodávám: který je schopen odemknout ${ }^{31}$ totalitu $^{32}$, zatarasení. Augustin mohl tímto dřevěným klíčem myslet Kristův kříž, na kterém nás smiřuje s Bohem Otcem (i apoštol Pavel si uvědomoval, jak je to skandální - tj. pro mnohé přinášející pohoršení - sr. Ga 5,$11 ; 1 \mathrm{~K} 1,23)$. Sám toho člověk není schopen; Lévinas to vyjadřuje radikálně: "Člověk by legitimně mohl přijmout odpuštění pouze tehdy, když druhým je Bůh nebo svatý“ ${ }^{33}$. Je zapotřebí skutečně živý, proměňující dia-log: Skrze přicházející výzvu, slovo, logos, je možné ze zatarasenosti sebou, v níž jsme schopni obstojně přežívat $v$ davu a společnosti, nacházet cestu ven, žít eticky, nejenom morálně - vnímat vztaženost, vazebnost či relaci, v níž již jsme ${ }^{34}$ - a učit se objevovat zcela jinou (totaliter aliter) cestu k druhým, světu, $k$ t/Ty.

\section{Literatura:}

- Aristotelés. (1996). Fyzika. Praha: Rezek.

- Aristotelés. (2003). Metafyzika. Praha: Rezek.

- Aristotelés. (2009). Politika. Praha: Rezek.

- Augustinus, A. (2004). Křestáanská vzdělanost: De doctrina christiana. Přeložila Jana Nechutová. Praha: Vyšehrad.

- Augustinus, A. (2007). O Boží obci: Knih XXII. Přeložila Julie Nováková. Praha: Karolinum.

- Dlouhá, J. (2018). Editorial 2018/XIII/1. Envigogika, 13(1). https:// doi.org/10.14712/18023061.576.

- Grant, G. (1986). Technology and Justice. Toronto: House of Anansi Press.

- Heidegger, M. (2004). Věda, technika a zamyšlení. Praha: OIKOYMENH.

- Heidegger, M. (2006). Básnicky bydlí člověk. Praha: OIKOYMENH.

- Heidegger, M. (2008). Rozvrh fenomenologické interpretace Aristotela. Praha: OIKOYMENH.

\footnotetext{
${ }^{30}$ Grant, G. (1986). Technology and Justice. Toronto: House of Anansi Press, s. 48.

${ }^{31}$ Srov. Platón. (2001). Ústava. Praha: OIKOYMENH, s. 213 (514a).

32 Augustinus, A. (2004). Křestáanská vzdělanost: De doctrina christiana, s. 189 (XI. 26).

${ }^{33}$ Levinas, E. (1998). Collected philosophical papers. Pittsburgh, Pa.: Duquesne University Press, s. 31.

${ }^{34}$ Sr. Sk 17,28. Sr. též Levinas, E. (1998). Collected philosophical papers, s. 43, 165.
} 
- Homér. (1980). Ílias. Přel. Rudolf Mertlík. Praha: Odeon.

- J Jeruzalémská biblická škola. (2009). Jeruzalémská Bible: Písmo svaté vydané J eruzalémskou biblickou školou. Překlad František X Halas, Dagmar Halasová. Kostelní Vydří: Karmelitánské nakladatelství.

- Komenský, J. A. (2017). Spisy o první filosofii. Praha: OIKOYMENH. Knihovna novověké tradice a současnosti.

- Lévinas, E. (1997). Čas a jiné/Le temps et l'autre, Praha: Dauphin.

- Lévinas, E. (1997). Totalita a nekonečno: Esej o exterioritě. Praha: OIKOYMENH.

- Levinas, E. (1998). Collected philosophical papers. Pittsburgh, Pa.: Duquesne University Press.

- Nietzsche, F. (1995). Tak pravil Zarathustra. Praha: Votobia.

- Platón. (2001). Ústava. Praha: OIKOYMENH.

- Rádl, E. (1946). Útěcha z filosofie. Praha: Čin.

- Ricoeur, P. (2000). Myslet a věřit. (Rozhovor). Praha: Kalich.

- Ricoeur, P. (2016). O sobě samém jako o jiném. Praha: OIKOYMENH.

- Sartre, J. P. (2006). Bytí a nicota. Praha: OIKOYMENH.

- Steel, S. (2018). Teacher Education and the Pursuit of Wisdom: A Practical Guide for Education Philosophy Courses. New York: Peter Lang.

- Svobodová, Z. (2013). Čas: Lidská otázka po původu a smyslu. Paideia: Philosophical e-journal of Charles University, roč. 10, č. 1.

- Szlezák, T. A. (2014). Za co vděčí Evropa Řekům: O základech naší kultury v řecké antice. Praha: Oikúmené.

- Weil, S. (1949). L'enracinement: Prélude à une déclaration des devoirs envers l'être humain. Paris: Les Éditions Gallimard. Dostupné na: http://classiques.uqac.ca/classiques/weil_simone/enracinement/weil_Enracinement.pdf.

- Weilová, S. (1996). Dobro, mez a rovnováha: Výbor ze Sešitů. Praha: Mladá fronta. 